\title{
OPOWIEŚĆ O YEXIAN JAKO PUNKT PRZECIĘCIA UNIWERSALNYCH ALGORYTMÓW TEMATYCZNYCH ${ }^{1}$
}

\author{
MARIANA ČECHOVÁ ${ }^{2}$ \\ (Uniwersytet im. Konstantyna Filozofa w Nitrze)
}

Słowa kluczowe: typ baśni 510 A, orientalne arcynarracje, analogie typologiczne

Key words: fairy tale type 510A, arch-narratives of the Orient, typological analogies

\begin{abstract}
Abstrakt: Mariana Čechová. OPOWIEŚĆ O YEXIAN JAKO PUNKT PRZECIĘCIA UNIWERSALNYCH ALGORYTMÓW TEMATYCZNYCH. „PORÓWNANIA” 17, 2015. T. XVII. S. 227-243. ISSN 1733-165X. Autorka, na podstawie wyników wieloletnich studiów i badań, próbuje zsyntetyzować wzajemne powiązania istniejących ustaleń, które dotyczą tematycznych analogii między typem baśni 510 A a innymi arcynarracjami (H. Bayley, R. D. Jameson, M. R. Cox, A. B. Rooth, F. Beauchamp, V. Mair, A. Waley, C. Reed etc.), a które dopełniają je przy tym o nowe związki. Sedno objaśnień, z którego autorka wyprowadza owe związki, stanowi pierwszą zapisaną opowieść tzw. kopciuszkowego cyklu (opowieść o Yexian, chińska prowincja Guangxi, ok. 850 r. n.e.). $\mathrm{Z}$ geograficznego punktu widzenia kieruje się przede wszystkim na wschodnie arcynarracje: przywołuje buddyjskie teksty Daśaratha-dżataka (V-I w. p.n.e.) i Sutrę Lotosu (mity o Guanyin, I w. n.e.), indyjską Ramajanę (poemat Walmikiema, ok. 500 r. p.n.e.), indyjskie eposy o Pangu (ok. 800 r. p.n.e.), chińskie teksty jak np. Pieśn niecichnacej boleści (806 r.), Wędrówkę na zachód (XVI w.), japońską opowieść Ochikubo monogatari (ok. 970 r.), jak również mity solarne (egipskie, sumeryjskie, akadyjskie, gnostyczne czy chrześcijańsko-żydowskie).
\end{abstract}

Abstract: THE STORY OF YEXIAN AS THE INTERSECTION OF UNIVERSAL ALGORITHMS
THEMATIC. “PORÓWNANIA" 17, 2015. Vol. XVII. P. 227-243. ISSN 1733-165X. The paper pre-
sents the synthesis and findings of the author's long-term study and research concerning the
thematic analogies between the fairy tale type 510A and other arch-narratives (H. Bayley, R. D. Jame-

${ }^{1}$ Studia te powstały $\mathrm{w}$ ramach projektu VEGA 1/0360/14 Osnovné tematické algoritmy $v$ slovesnom umení (s intersemiotickými a interdisciplinárnymi presahmi).

2 Correspondence Address: mcechova@ukf.sk 
son, M. R. Cox, A. B. Rooth, F. Beauchamp, V. Mair, A. Waley, C. Reed, etc.). The findings are further supplemented with new connections and observations. The core of the exposition is based on the first recorded story of the Cinderella cycle (the story of Yexian, the Chinese province Guangxi, ca. A.D. 850). The focus of the paper is mostly on the Eastern arch-narratives: the Buddhist texts Dasharathajataka ( $5^{\text {th }}-1^{\text {st }}$ century B.C.) and the Lotus Sütra (the myths about Guanyin, $1^{\text {st }}$ century A.D.); the Hindu texts the Ramayana (Valmiki's poem, ca. 500 B.C.) and epics about Bubo and Manu and the fish (about 800 B.C.); the Chinese texts such as A Song of Unending Sorrow (806) and Journey to the West (16 th century), a Japanese story Ochikubo Monogatari (ca. 970) and the solar myths (Egyptian, Sumerian, Akkadian, Gnostic and Judeo-Christian).

\section{Wstęp}

W poniższym artykule zamierzam wskazać tematyczne analogie zachodzące pomiędzy niektórymi orientalnymi narracjami a wariantami w baśniowym typie 510A o "prześladowanych bohaterkach“. Szczególną uwagę pragnę poświęcić starochińskiej opowieści o Yexian. Swój wywód przeprowadzę w następujących, eksplanacyjnych krokach:

- wyznaczę najpierw podstawowe cechy charakteryzujące baśń typu 510A;

- następnie porównam go ze wspomnianą starochińską narracją;

- interesować mnie będą przy tym także paralele między jej (tzn. starochińskiej narracji) fabułą, ewentualnie między pojawiającymi się motywami a innymi orientalnymi arcynarracjami;

- na zakończenie wskażę kilka hipotez wyjaśniających niezwykłe, transkulturowe rozproszenie przedstawionego baśniowego typu.

W międzynarodowej klasyfikacji typów baśni stworzonej przez Antti Aarnego, Stitha Thompsona i Hansa-Jörga Uthera ${ }^{3}$ (dalej jako ATU) typ baśni o „prześladowanych bohaterkach" został oznaczony jako typ baśni 510A. Zawiera on zbiór opowieści, znanych jako opowieści o Kopciuszku.

ATU obejmuje baśniowy typ narracji i zgodną podstawę fabuły. Dzięki temu może być punktem wyjścia typologicznie powiązanych wzajemnie różnych opowieści, które pochodzą z tradycji rozlicznych grup etnicznych, rozmaitych epok i które są włączone także do innych gatunków niż baśń.

${ }^{3}$ Numeryczną klasyfikację europejskich baśniowych treści opracował na początku XX w. fiński folklorysta Antti Aarne, przedstawiciel szkoły historyczno-geograficznej (Verzeichniss der Märchentypen, 1910). Amerykański badacz Stith Thompson (Antti Aarne - Stith Thompson: The Types of the Folktale) uzupełnił ją następnie o pozaeuropejskie treści i opracował $\mathrm{w}$ dwóch zrewidowanych wydaniach (1928, 1961). Tymczasem ostatnią innowację katalogu zawiera międzynarodowy indeks klasycznych typów narracyjnych (The Types of International Folktales), który w 2004 r. został zestawiony przez niemieckiego literaturoznawcę Hansa-Jörga Uthera. 
Baśniowy typ wyznacza inwariantne struktury. Chodzi o stałe komponenty, schematy tematyczne, funkcje postaci pod względem fabuły i znaczeniotwórcze położenie w opowieści. Opis baśniowego typu kompleksowo dotyczy jego wątku fabularnego.

Baśniową treść typu 510 A o „prześladowanych bohaterkach” wyróżnia, według klasyfikacji ATU, niezmienny rdzeń:

1) macocha bezlitośnie obchodzi się z bohaterką;

2) bohaterka zmuszana jest do wykonywania ciężkich albo upokarzających ją prac;

3) bohaterka spotyka księcia albo książę niebezpośrednio dowiaduje się o jej istnieniu, o jej pięknie i wyjątkowości;

4) bohaterka zostaje zidentyfikowana;

5) dochodzi do zaślubin.

\section{Opowieść o Kopciuszku jako arcynarracja}

Współcześnie wiadomo, że baśń o Kopciuszku modyfikowano ponad tysiąc razy, a zmiany te zanotowano $\mathrm{w}$ różnych częściach świata. $\mathrm{W}$ procesie tym wielką rolę odegrała angielska folklorystka Marian Roalfe Cox, która w XIX w. zgromadziła i przy wykorzystaniu metody komparatystycznej opracowała trzysta czterdzieści pięć wariantów tej opowieści z ponad osiemdziesięciu krajów świata, wliczając indyjskie, armeńskie, annamskie, syryjskie czy algierskie narracje, np.

- Francja: Cendrillon (Kopciuszek)

- Niemcy: Aschenputtel (Kopciuszek)

- Czechy: Tři sestry (Trzy siostry),

- Rosja: Vasilisa prekrasnaya i Chernushka (Przepiękna Wasylisa i Czernuszka)

- Gruzja: Conkiajgharuna (The Little Rag Girl)

- Norwegia: Kari Trestakk i Lita Kjarsti (Katie Woodencloak// Kari Woodengown)

- Dania: Guldskoen

- Szwecja: Askungen

- Jutlandia: Ludse Lurvehotte

- Irlandia: Fair, Brown and Trembling

- Szkocja: Rashin-Coatie

- Japonia: Benizara kakizara

Do prac M. R. Cox nawiązywała szwedzka folklorystka Anna Birgitta Rooth. W studium The Cinderella cycle z roku 1951 przeanalizowała siedemset wersji Kopciuszka. Własne badania poszerzyła o opowieści na przykład z Indonezji, Malezji, Indochin, Kambodży, Chin, Pakistanu, Afganistanu, Iranu, z państw Półwyspu Arabskiego, Madagaskaru, Angoli i Chile.

Typ baśni o Kopciuszku (510 A) jest bogato reprezentowany także w tradycji słowackiej. Należą do niego, na przykład, baśnie Dva holúbky (Dwa gołąki), Tri 
holúbky (Trzy gotabki), Pastorkyňa (Pasierbica), O troch dievkach (O trzech pannach), O Popolušce (O Popoluszce), O Popolníčke (O Popielniczce), O jednej pastorkyni (O jednej pasierbicy), Sirota Ilka (Sierotka Ilka) a O sirote a o královi (O sierocie i o królu).

Angielski badacz Harold Bayley, który w dziele The Lost Language of Symbolism (1912) skoncentrował się na gruntownej interpretacji historii o Kopciuszku, ogłosił (hipo)tezę, że modyfikacje tej opowieści tworzą podstawę dla połowy światowych baśni. Bez utożsamiania się z tym kategorycznym twierdzeniem, które ze względu na czas, gdy było formułowane (1912), przeszło wielokrotną i metodologicznie różnorodną obronę (Pace), możemy tylko konstatować, że typologiczno-tematyczne analogie opowieści o Kopciuszku nie ograniczają się tylko do baśni (tak jak powiedzmy $O$ dvanástich mesiačikoch ( $O$ dwunastu księżycach), Kráska a zviera (Piękna $i$ bestia), Zlatý kolovrátok (Złoty kołowrotek), Zlatovláska (Złotowtosa), Snehulienka (Śnieżynka), Sol' nad zlato (Sól nad złoto), Mrázik (Mróz), Janko a Marienka (O Janku i Mariance), Pani Zima (Pani Zima), Najmilši Roland (Ukochany Roland), Jalovec (Jałowiec), Kožušinka (Kożuszek), Jednoočka, dvojočka a trojočka (Jednooka, dwuoka i trójoka), Biela a čierna nevesta (Biała i czarna panna młoda), Jelenček (Jelonek), Ružová Anička (Różowa Anusia), Vlkolak (Wilkołak) etc.), ale sięgają także do innych gatunków (opowieść Amor i Psyche z powieści Apulejusza Metamorfozy albo Złoty osiot, japońska opowieść Ochikubo monogatari, tragedia Shakespeara Król Lear etc.). Niewątpliwie chodzi w nich o fakt, że dobroduszna dziewczyna albo chłopak jest wyszydzana/-y przez pokrewne albo niepokrewne, bliskie bądź dalsze osoby (siostry, macocha, teściowa, ojciec etc.).

Ich fabularna/treściowa osnowa zbudowana jest na algorytmie interakcji z krewnymi jako osobami "pasożytniczymi“, nie tylko we wstępnych epizodach opowieści, ale także w dalszym jej przebiegu:

1. Znęcanie się przez macochę nad nieswoim/nieswoimi dzieckiem/dziećmi.

2. Pozbycie się go/ich (wypędzenie, wyprowadzenie do lasu, zaczarowanie, zabicie).

3. Dziecko/dzieci znajduje/znajdują pomoc.

4. Po otrzymaniu pomocy - powrót do domu.

5. Macocha zostaje ukarana (wygnana, spotyka ją śmierć).

Linearne następstwo aktów, zawartych w tej pentadycznej treściowej osnowie, przeplata się również z „kopciuszkową" opowieścią.

Pozostałe klasyczne baśnie można, według owego kategorycznego wniosku Bayleya, uważać za luźniejsze odmiany Kopciuszkowego cyklu, czyli za dywergentne warianty opowieści o dewiacyjnym, odrzuconym stworzeniu, które w koncu wykracza poza swoją tragiczną sytuację i zyskuje wysoki status. Ten przełom, w którym bohaterka powstaje $\mathrm{z}$ "popiołu” - stanu poniżenia i wstępuje do stanu przyzwoitości, wzniosłości i dumy - pojawia się, według Bayleya, w wielu starożytnych mitach: sumeryjskich, egipskich, gnostycznych czy chrześcijańsko-żydowskich. Predestynacja ich głównych protagonistek, np. spersonifikowanej gnostycz- 
nej mądrości Sofii, asyryjskiej Isztar, sumeryjskiej Inanny, greckiej Psyche czy biblijnej Sulamit, bezwzględnie zakłada kontakt z niższą sferą świata naturalnego. Charakterystyczna dla niej jest ciemność, przepastna pustka, chaos, beznadziejność, smutek, boleść i cierpienie. Po zaznaniu tego dręczącego etapu, dochodzi do wyraźnego zwrotu i wzrostu - osiągnięcie wzniosłego (boskiego) stanu, pełni i nieśmiertelnej lekkości bytu .

Na poziomie archetypów wspomnianych narracji można wyróżnić następujące „kopciuszkowe” motywy:

- zachowanie macochy/teściowej/siostry, będące źródłem zmartwień i trosk głównej bohaterki;

- misterium przemiany przy udziale i pomocy „prawdziwej” matki;

- szukanie żony przez księcia;

- królewski ślub i wesele.

Okazuje się zatem, że baśniowy typ 510 A przedstawia z typologicznego punktu widzenia arcynarracji praopowieśc z uniwersalnym, genologicznie transwersalnym, tematycznym algorytmem czy jądrem fabuły.

\section{Opowieść o Yexian i jej orientalne typologiczne analogie}

Przytoczone stwierdzenia i (hipo)tezy spróbujemy rozszerzyć o kolejne relewantne fakty i zależności. Szczególną uwagę skupimy na najstarszej, zapisanej

${ }^{4}$ Przytoczmy kilka przykładów. Asyryjska bogini Isztar, córka Boga Światła Sina, zstępuje ze swego niebiańskiego królestwa do podziemnego królestwa ciemności. Przy każdej z siedmiu bram wejściowych do tego beznadziejnego świata musi zdjąć jakąś część swojego królewskiego stroju. Przed władczynią podziemnego świata - Allatą - staje zupełnie naga, słaba i bezbronna. Allata wykorzystuje tę sytuację i zsyła różne schorzenia i choroby. Isztar mimo tego nie zostaje na zawsze w niewoli. O męczarniach Isztar dowiadują się jej rodzice-bogowie, którzy powołują do życia niebiańskie stworzenie Udusz-Namira (to nominum prioprium oznacza "olśniewające światło"). On pomaga jej wrócić do "górnego", wyższego świata. Isztar, która przed wejściem do królestwa ciemności pozbawiona została cennych sukni, odzyskuje je ponownie w drodze powrotnej, według Bayleya jest figuralną wersją Kopciuszka; Allata odpowiada okrutnej macosze a Udusz-Namir pełni rolę księcia.

W podobnym sumeryjskim micie również dochodzi do zejścia głównej bohaterki - bogini Innany - (ekwiwalent bogini Isztar) do ciemnej krainy za swoją siostrą Ereszkigalą. Po drodze do podziemia strażnik przy każdej z siedmiu bram odbierze Innanie jakiś drogocenny klejnot. Po trwającej trzy dni „śmierci”, czyli po rozłące ze światłem i światem, z którego pochodzi, pojawi się bóg mądrości Enkim - który ją uratuje.

W gnostycznym micie o Sofii dusza zostaje ucieleśnieniona i przedstawiona jako córka Bogini Matki i Boga Ojca. Dziewicza Sofia symbolizuje mądrość i jednocześnie boskie światło, przenikające wszelkie stworzenie. Sofia rodzi córkę, będącą odbiciem niej samej, która zejdzie do niższych światów. Między sferami światła i ciemności rozpościera się jednak zasłona, która uniemożliwia Sofii powrót. Odłączona, zmęczona cierpieniem, niepokojem i żalem, stwarza ziemię. Osamotniona w ciemności i pustce lamentuje, wzywa swoją Wielką Matkę. Ta z kolei prosi o pomoc Stworzyciela Wielkie Światło. Stworzyciel posyła Chrystusa, swojego Syna, który promienieje i schodzi do Sofii. 
wersji opowieści o Kopciuszku. Wiąże się ona ze starożytnymi Chinami: w czasie panowania dynastii Tang, około 850 r. n.e., zapisał ją Duan Chengshi (poeta, pisarz, urzędnik i uczony z dynastii Tang). Opowiedział mu ją służący Li Shiyuan (członek grupy etnicznej Zhuang) w mieście Nanning, które jest częścią prowincji Guangxi w pobliżu granicy z Wietnamem.

Przybliżmy pokrótce opowieść o Yexian: w okresie panowania dynastii Tang żył jaskiniowy naczelnik nazywany $\mathrm{Wu}$, który dwukrotnie się ożenił5. Pierwsza żona urodziła mu córkę o imieniu Yexian. Szybko jednak zmarła, po kilku latach zmarł także i Wu. Yexian zaczęła pracować jako służąca w domu swojej macochy. Macocha nieustannie szykanowała swoją nierodzoną córkę, posyłała ją po drewno $\mathrm{w}$ niebezpieczne miejsca i po wodę do niepewnych źródeł. Pewnego dnia Yexian złowiła małą rybkę o wielkości dwóch palców z czerwonymi płetwami i złotymi oczkami. Rybka z dnia na dzień coraz bardziej rosła, więc dziewczyna musiała ją w końcu wpuścić do stawu. Ryba ze stawu wynurzała się tylko wtedy, gdy na brzegu pojawiała się Yexian. Macocha zorientowała się, co się dzieje. Pod wymyślonym pretekstem odesłała Yexian, a sama przebrała się w jej zniszczone i brudne ubrania i udała się do stawu. Przywołała rybę, a kiedy ta wynurzyła się z wody, macocha zabiła ją, następnie zjadła, a ości wyrzuciła. Kiedy dziewczyna się o tym dowiedziała, gorzko zapłakała w osamotnieniu. Wtedy też z nieba zjawiła się istota $\mathrm{z}$ potarganymi włosami i w zaniedbanym ubraniu. Poleciła Yexian, żeby odnalazła ości ryby i schowała je w swoim pokoju. Gdy będzie czegokolwiek potrzebować, wystarczy, że zwróci się do ości i otrzyma to, czego pragnie. Dziewczyna uczyniła to, co powiedziała jej niebiańska istota, tym sposobem zyskała tyle złota, pereł, szat i jedzenia, ile tylko zapragnęła. Gdy nadszedł czas jaskiniowych uroczystości, macocha wybrała się na nie ze swoją córką, a pasierbicy przykazała, żeby została $\mathrm{w}$ domu i pilnowała drzew owocowych $\mathrm{w}$ ogrodzie. Dziewczyna czekała aż macocha się oddali; sama też wybrała się na uroczystości. Ubrała płaszcz utkany z piór zimorodka, a na nogi włożyła buty ze złota. Przy ucieczce

\footnotetext{
${ }^{5} \mathrm{Tu}$ warto dodać kilka słów na temat wielożeństwa w dawnych Chinach. Otóż funkcjonowały wówczas dwa modele małżeństw: monogamiczne i poligamiczne, jednakże małżeństwa zawierane zasadniczo były poligamiczne. Tolerancja, ale także rygorystyczne przestrzeganie form zachowania zmuszające do obopólnej grzeczności, stanowiły podstawę utrzymania takiego małżeństwa. Nie mogło być mowy o zazdrości erotycznej, chodziło raczej o zazdrość o pozycję społeczną. Żony pozwalały bowiem mężowi na pozamałżeńskie stosunki płciowe, ale musiały się one odbywać z kobietami niższego stanu, pozycji społecznej. Wielożeństwo w dawnych Chinach było zjawiskiem o szerszej skali niż w innych systemach kulturowo-cywilizacyjnych. Osoby pochodzące z niższych warstw posiadały najwyżej jedną żonę; osoby na wyżej postawione posiadały już żony główne i żony poboczne; im zamożniejsza osoba, tym więcej posiadała żon i nałożnic, np. w klasie średniej mężczyźni mieli od 3 do 12 żon i nałożnic, warstwy wyższe 30 i więcej). Pierwsza żona musiała pochodzić zwykle z tej samej warstwy społecznej co mąż, natomiast żony poboczne mogły już pochodzić z niższych warstw (wśród nich było wiele prostytutek).
} 
$\mathrm{z}$ balu, w obawie, żeby nie poznała jej macocha, zgubiła bucik. Znalazł go jeden $\mathrm{z}$ mieszkańców jaskini i sprzedał ją w T’o Han w pobliskim królestwie. Bucik szybko dostał się do rąk króla. Władca zaprosił do siebie wszystkich obywateli, aby ci przymierzyli but. Pantofelek jednak był o jeden palec mniejszy od tej najmniejszej ze stóp, nie pasował więc na żadną nogę. Po pewnym czasie, gdy król przeszukał wszystkie domy w królestwie w poszukiwaniu właścicielki bucika, odnalazł Yexian. Zmusił ją, żeby przymierzyła pantofelek. Okazało się, że leży jak ulał. Król wziął Yexian za żonę i ustanowił ją najważniejszą z żon. Ości ryby spełniały, przez pierwszy rok każdą prośbę chciwego króla, który się wzbogacił. $\mathrm{W}$ drugim roku jego prośby jednak nie były wysłuchiwane. Król zagrzebał więc ości razem ze swoim bogactwem na brzegu stawu; po krótkim czasie skarby odkrył generał królewskiego wojska i wykorzystał je do wyposażenia armii. Pewnej nocy ości zmył odpływ.

Chińska opowieść o Yexian, którą przybliżyłam w sporym skrócie, i europejskie warianty historii o Kopciuszku ewidentnie wskazują na kilka tematycznych i motywowych pararel:

1. Bohaterka jest znienawidzona i poniżana przez macochę oraz przyrodnią siostrę;

2. Okazuje życzliwość zwierzętom - tu: rybie (w europejskich wersjach chodzi o krowę, cielaka etc.);

3. W najgorszych momentach życia z pomocą przychodzi jej pozaziemska istota (u Perrault'a chodzi o kumę-rusałkę, u braci Grimm o inkarnowaną martwą matkę);

4. Protagonistka wybiera się na królewską uroczystość incognito w niezwykłych szatach;

5. Przy pospiesznym wyjściu z balu gubi trzewik, który okaże się pomocny przy rozpoznaniu bohaterki;

6. Ślub z królem.

Na preliminarnych badaniach azjatyckich korzeni opowieści o Yexian koncentrowała się amerykańska badaczka Fay Beauchamp (Asian Origins of Cinderella, 2010). Jak już wspomniałam, pierwszą zapisaną historię o Kopciuszku/Yexian opowiedział w wieku IX członek grupy etnicznej Zhuang. Beauchamp w związku z tym podkreśla, że teren Zhuang w IX wieku stanowił skrzyżowanie różnych kultur. Członkowie tej grupy w tym okresie, wchłaniali, a jednocześnie autonomicznie dorównywali hinduistycznym i buddyjskim wpływom z południowej i południowowschodniej Azji, jak również kulturowej dominacji chińskiej grupy etnicznej Han.

Beauchamp genetycznie wyprowadza historię o Yexian przede wszystkim $\mathrm{z}$ indyjskich korzeni, które były dostępne chińskim obywatelom Zhuang (i to już w IX w., kiedy opowieść o Yexian była zapisana). 
Jeśli tak założymy, oznaczać to będzie, że indyjskie, pisemnie utrwalone pierwotne wersje opowieści o Yexian pochodzą z okresu, który obejmuje od V do I w. p.n.e. do XI w. n.e. Do nich należy także buddyjska dżataka ${ }^{6} \mathrm{z}$ nazwą Daśaratha. Daśarathadżataka zawiera opowieść o Site, która nawiązuje do hinduistycznej $R a$ majany.

Ramajana jest prototekstem, który, według Beauchamp, odgrywa kluczową rolę w związku z historią o Yexian. Mieści opowieść o Site, która od powstania dzieła Walmikiema Ramajana ok. 500 r. p.n.e. w różnych postaciach weszła do ciągłego, komunikacyjnego obiegu. Dzieje Site i Yexian przeplatają się z perspektywy tematycznych algorytmów:

1) rywalizacja między wieloma żonami i niewłasnymi dziećmi;

2) wygnanie dziewczyny i pozbawienie jej odzieży, która wyraża prawdziwą tożsamość;

3) pojawienie się istoty pozaziemskiej - nadprzyrodzonego pomocnika/posła, który zjawia się pod postacią zwierzęcia, żeby pomóc bohaterce;

4) rola złotych pantofelków;

5) ślub z królem/objęcie tronu.

Przytoczmy zatem niektóre ze wspomnianych wyżej wspólnych tematycznych i motywowych segmentów indyjskiej historii o Site i chińskiej o Yexian.

Przywołana buddyjska dżataka jest zwięzłym podaniem, opowieścią o tym, jak król Daśaratha nieuważnie przyobiecał swojej o wiele młodszej drugiej żonie, że jej syn Bharata odziedziczy tron zamiast starszego syna pierwszej żony, Ramy. Rama musi zmierzyć się ze swoim wygnaństwem i razem z Site, swoją małżonką, zamieszkuje w lesie, gdyż darzy swego ojca wielkim szacunkiem, jest posłuszny jego woli.

W Daśaratha-dżatake i w Ramajanie okrutne zachowanie macochy umotywowane jest rywalizacją między pierwszą i drugą żoną. $Z$ tego względu, że historia dotyczy dzieci, stawka jest wysoka: matka królewskiego dziedzica zyskuje prestiż, siłę i komfort, z kolei druga małżonka zostaje poniżona razem ze swoimi dziećmi.

Ojciec Yexian także posiada dwie żony, przy czym ta druga we wszystkich znanych nam przekładach określona jest mianem "macochy".

Opowieść ową, podobnie jak tę o Ramie, można pojmować jako opowiadanie o lepszym dziedzicu, który dopłaca do tego, że podważane zostają jego pierworodne prawa.

W historii o Site podkreślona jest rola zwierzęcego pomocnika - Hanumana. Hanuman to inkarnowany bóg w postaci zwierzęcia (małpy). Dzięki temu ratuje bohaterkę w trudnej sytuacji, gdy jest "poza zasięgiem ludzkiej pomocy“. To właśnie Hanuman, a nie Rama, odnajduje Sitę, gdy porwie ją demon Ravana. Rozpoznaje ją dzięki talizmanom wysadzanym szlachetnymi kamieniami, pociesza ludzką mową i planuje uwolnienie. Jego zamiarem jest połączenie nieskalanej Site z królem Ramem. Można stwierdzić, że zadanie Hanumana w opowieści o Yexian

\footnotetext{
${ }^{6}$ Dżataka to opowieści o poprzednich wcieleniach Buddy, datowane od III w. p.n.e.
} 
jest podzielone między „istotę z włosami spływającymi na plecy i w zaniedbanym ubraniu, która zstąpiła z nieba" (Mair 2005: 365) a małą czerwoną rybkę (według Perraulta analogicznie w Kopciuszku, to zadanie rozdzielone jest między kumęrusałkę i gołębie). Ryba-pomocnik z historii o Yexian ukazuje, podobnie jak Hanuman, szczególną kombinację tego, co ludzkie, zwierzęce i boskie.

Podczas największej niedoli Yexian objawi się stworzenie z nieba, które przedstawia - według Beauchamp - albo martwą matkę dziewczyny, albo jej ojca. Istnieje wiele przekładów opowieści o Yexian, które nie wykluczają tej wykładni. Mair $\mathrm{w}$ uwagach do cytowanego przykładu („,istota $\mathrm{z}$ włosami spływającymi na plecy i w zaniedbanym ubraniu, która zstąpiła z nieba") eksplicytnie zwraca uwagę, że określenie „istota” jest rodzajowo niejednoznaczne.

W chińskiej opowieści o Yexian macocha zabrania dziewczynie wzięcia udziału w uroczystościach. Rozkazuje jej, aby ta „pilnowała drzew owocowych na dworze" (Mair 2005: 365). Inni tłumacze używają zamiast słowa "dwór" wyrazu „ogród" (Waley 1963: 150; Reed 2001: 12). Następnie, gdy macocha wraca z uroczystości, znajduje śpiącą Yexian z rękoma „owiniętymi wokół pnia drzewa owocowego" (ibidem). W jednej z głównych scen Ramajany Hanuman odnajduje Sitę w przestrzeniach pałacu Ravana, do tego w ogrodzie "pełnym drzew owocowych, które kwitły przez cały rok" (R. i S. Goldman 1996: 153). Sita siedzi pod kwitnącym drzewem choruny strzelistej, in. aszoki (por. polyalthia longifolia), a Hanuman zagaduje ją $\mathrm{z}$ konaru.

Z kolei w pochodzącej z XVI w. chińskiej powieści Wędrówka na zachód, pojawia się postać małpiego króla, który ma nakaz chronienia drzew owocowych. Bogowie, chcąc zatrzymać małpiego króla na miejscu, polecają mu doglądanie „ogrodu nieśmiertelnych brzoskwiń". Król małp buntuje się wobec władzy. Zdejmuje "czapkę i ubranie", chodzi po drzewach i zajada się brzoskwiniami, następnie ubiera się i tak „rozrabia dwa albo trzy dni” (Yu 1977: 135-136). W przebraniu wybiera się, podobnie jak Yexian, na zapowiadaną wspaniałą zabawę.

Należy podkreślić, że, podobnie jak małpi król, także Yexian poprzez zmianę stroju ukrywa (albo odkrywa) swoją prawdziwą tożsamość, by wyzwolić się z niewoli i zmienić swoje życie.

Sita i Yexian uciekają z niewolniczego położenia. Drzewo, dające schronienie i otuchę jest, dla obu częścią pełnego dobroci uniwersum.

Różnica polega na tym, że w historii o Yexian protagonistka zostaje nagrodzona, podczas gdy w hinduistycznym narracyjnym modelu świata ostatecznie nagrodzony jest męski protagonista (król Rama), dlatego że przestrzega dharmy7.

Najwyraźniejszym typologicznym spoiwem (w odróżnieniu od Beauchamp, nie odważylibyśmy się mówić tu o powiązaniach genetycznych) między Ramajaną a opowieścią o Yexian jest symbol złotych trzewików. Nogi, jako część królewskiej wła-

${ }^{7}$ Dharma - w hinduizmie tym słowem określano podstawowe prawa karmiczne, które decydowały o wydarzeniach w życiu człowieka. Był to także rodzaj tajemnej wiedzy na temat tych praw. 
dzy i tożsamości stanowią motyw, który znajduje się także w pełnej wersji Walmikiema z V w. p.n.e. Sita zidentyfikowana jest tu dzięki bransoletom przy kostkach.

We wspomnianej buddyjskiej dżatace główną rolę odgrywają buty. Opowieść ma zgodną przemianę, wynik: przyrodni brat Ramy - Bharata znajduje Ramę na wygnaniu, Rama jednak odrzuca propozycję wcześniejszego powrotu - musi minąć czas jego banicji. Bharata decyduje się zatem na samotny powrót, ale z trzewikami Ramy: „Pantofle władały królestwem trzy lata. Dworzanie na królewskim tronie położyli słomiane buty. Trzewiki rozsądzały pojedyncze przypadki. Jeśli jakaś sprawa nie była dobrze rozsądzona, buty zaczęły o siebie uderzać" (Cowel 1957: 82). Tym cudownym sposobem pantofle zatem zastępowały tożsamość Ramy i potwierdzały jego królewskie pochodzenie.

O ile wersja dżataki nie określa sandałów Ramy jako „złotych”, o tyle w Ramajanie Walmikiema padają z ust Bharata słowa:

Sam mój brat powierzył w moje ręce królewski majestat jako zobowiązanie - te złotem ozdobione trzewiki zapewnią szczęście i bezpieczeństwo królestwu... O, gdybym tylko mógł jak najszybciej ujrzeć nogi Ramy obute w te trzewiki i mógł znów je zasznurować swoimi rękoma (Pollock 1986: 314).

Historia o Ramie podsuwa także niebezpośrednie wyjaśnienie kwestii, dlaczego but, który pomaga zidentyfikować swojego właściciela, w opowieści o Kopciuszku odgrywa rolę kluczowego rekwizytu. Rozpoznanie „właściwego władcy”, ewentualnie prawdziwej „królowej”, wprowadza równowagę i sprawiedliwość.

To, że hinduistyczna Ramajana była w południowowschodnich Chinach, $\mathrm{w}$ których powstała historia o Yexian, znana, podkreśla też fakt, że $\mathrm{w}$ południowym Wietnamie, w VII w. znajdowała się świątynia poświęcona Walmikiemu.

Nie chcę tym samym sugerować, że opowieść o Site i Ramie wpłynęła na historię o Yexian, która została zapisana cztery stulecia później, ale pragnę tylko wskazać na fakt, że popularyzacja Ramajany pokryła się z obszarem powstania dziejów Yexian, czyli regionem między północnym Wietnamem a chińską prowincją Guangxi.

Hipoteza Beauchamp uwydatnia, że opowieść o Yexian jest oryginalnym dziełem Zhuangów, którzy zestawili w nim motywy zaczerpnięte $\mathrm{z}$ własnej tradycji i doświadczenia z motywami pochodzącymi z o wiele obszerniejszych opowieści, jak np. opowiadanie o Ramie i Site.

\section{Opowieść o Yexian i narracje o Pangu i o Manu}

Historia o Yexian posiada dwie linie narracyjne: jedna opowiada o uratowaniu ryby, druga natomiast koncentruje się na zaniedbanym wyglądzie istoty pozaziemskiej, która pomaga dziewczynie w beznadziejnej sytuacji. Obie mają, według Beauchamp, hinduistyczne i buddyjskie analogie. 
Przypuszczenie, że hinduistyczne opowieści były znane Zhuangom, wzmacnia fakt istnienia eposu o Pangu (określony jako „zhuangski mit z prowincji Guangxi"). Opowieść łączy z narracją o Yexian sekwencja motywu z rybą. Nie zawiera natomiast motywów, które na Zachodzie odbierane są jako wyraźne znaki opowiadania o Kopciuszku: brakuje tu więc obrazu macochy, przyrodniej siostry, udręczonego dziecka, uroczystości, nadprzyrodzonego pomocnika, trzewików, sukni i królewskiego wesela. W historii o Pangu mowa jest o jego dzieciach, które przeżyją potop, dlatego, że okazały miłosierdzie Bogu Piorunów i bezinteresownie go uratowały. Dzięki ich dobremu sercu (i płodności), ludzkość nie wyginęła.

Opowieść tę łączy z chińską narracją o Yexian motyw małej ryby, która urośnie do sporych rozmiarów. W obu narracjach (opowieść o Pangu i opowieść o Yexian) zastępcy hierarchicznie zwierzchniej, władającej społecznie warstwy zostają ukarani, gdy tymczasem litościwa Yexian i dzieci Pangu są docenione.

Motyw potopu w opowieści o Pangu prowokuje Beauchamp do postawienia odważnej hipotezy, według której opowiadanie o Yexian jest po części wywiedzione z hinduistycznej opowieści o Manu i rybie. Niewątpliwie, niektóre motywy tej narracji są zbliżone do opowieści o Yexian $\mathrm{w}$ dosłownym i symbolicznym znaczeniu. $\mathrm{W}$ obu przypadkach ratowanie ryby przybiera trójstopniowy proces: ryba kolejno przeobraża się do większych rozmiarów, osiąga nadnaturalną wielkość i w końcu zostaje wypuszczona do wody. Manu, jak również Yexian, ukazują swoje miłosierdzie. $\mathrm{W}$ obu historiach ta łaskawość objawia się obopólnie: człowiek pomaga rybie, a ryba pomaga człowiekowi (Yexian troszczy się o rybę, potem ryba troszczy się o Yexian; Manu ocala rybę, potem ona ocala go przed potopem).

Ryba Manu jest, podobnie jak Rama, wcieleniem (awatarem) boga Wisznu, czyli Wisznu we wcielonej postaci. O ile podobieństwa hinduistycznych opowieści o Ramie, Site i Hanumanie czy Manu i rybie z narracją o Yexian nie można potwierdzić powyższymi argumentami, o tyle Beauchamp uważa to podobieństwo z obiema narracjami o wcieleniach Wisznu za okoliczność potwierdzającą przypuszczenie, że główne źródło narracji o Yexian jest hinduistyczne.

\section{Opowieść o Yexian i paralelizmy $z$ innymi orientalnymi narracjami}

Kolejną współbrzmiącą opowieścią chińskich Hanów, na którą powołuje się R. D. Jameson (1931: 91), jest ta opowiedziana w powieści Wẹdrówka na zachód z XVI wieku. To historia o tym, jak Guanxi wypuścił na wolność złotego karpia (Yu 2001). Nie wie, że chodzi o Rzecznego króla smoków. Ten z kolei powie mu potem: 
Życzliwość trzeba odwzajemniać życzliwością. Dzisiaj muszę tobie uratować życie, żebym mógł odwzajemnić twoje miłosierdzie... To ja byłem tym złotym karpiem, którego uratowałeś, jesteś zatem moim dobroczyńcą (Yu 2001: 202).

Podobieństwo opowieści o Yexian z przytoczoną narracją nie polega tylko na tym, że mały złoty karp wyrasta na olbrzymiego Rzecznego króla smoków, ale przede wszystkim w epimicie, według którego życzliwość jest nagrodzona wzajemną życzliwością (analogicznie jak w eposie o Pangu i w opowieści o Manu i rybie).

W literaturze chińskich Hanów znany jest wiersz, wraz z którym rozszerzył się we wschodniej Azji zdarzeniowy algorytm o cesarzu, który zakochuje się w młodej piękności, a wywyższeniem jej ponad inne swoje małżonki, naruszył tradycję (podobnie jak to uczynił król z Yexian). Algorytm ten zawiera opowiadanie o faktycznym cesarzu Xuanxong z dynastii Tang. Bai Juyi napisał w 806 r. Pieśn niecichnacej boleści ${ }^{8}$. W Chinach był to ogólnie znany utwór, który mogli poznać Duan Chengshi i jego sługa Li Shiyuan (dokumentujący opowieść o Yexian). Wiersz opowiada o "najdroższej małżonce” cesarza Xuanxonga o imieniu Yang Guifei (historycznie rzeczywistej postaci), która, podobnie jak Kopciuszek, „,awansowała” ze "szmat do wzniosłych szat": z pozycji podrzędnej dwornej damy osiąga pozycję guifei („najdroższej małżonki”) - porównać to można ze statusem Yexian jako "pierwszej żony". Ta romantyczna legenda o Yang Guifei, szerzona w Chinach po roku 807, stworzyła przestrzeń dla silnych, intertekstualnych nawiązań. Dotyczy to także japońskiej opowieści Ochikubo monogatari (ok. 970 r.) nieznanego autora. Ochikubo była półsierotą, córką radcy dworu Tadayoriego, który ponownie się ożenił. Zła macocha zmuszała dziewczynę do spania w zagłębieniu usytuowanym pośrodku izby, poniżej podłogi zbudowanej jedynie wzdłuż ścian (spotykane częste tłumaczenie ochikubo jako piwnicy czy komórki wynikać może z uproszczenia lub też nieznajomości tradycyjnej architektury wnętrz Japonii) ${ }^{9}$.

Buddyjska Sutra Lotosu, która po raz pierwszy została przełożona na język chiński w 406 r., zawiera opowieść o „Córce Króla Smoków”, która przekonuje, że także kobieta może osiągnąć oświecenie, jak również część nazywaną "Guanyin sutra" (de Bary and Bloom 1999: 453-455). Możliwy związek między Yexian a poważaniem Guanyin wzbogaca wykładnię opowieści o Yexian o nowe konwencje.

Zapisana w IX w. w Chinach opowieść o Guanyin ukazuje historię pięknej, ale nie posiadającej dobrego pochodzenia, młodej kobiety handlującej rybami, która swoim adoratorom daje do zrozumienia, że wyjdzie za tego, kto przedstawi jej interpretację Sutry Lotosu. Udaje się to tylko młodzieńcowi o imieniu Mero. Dziewczyna obiecuje mu, że będzie jego żoną, zaprasza do domu swoich rodzi-

8 Song of Lasting Pain - przekład Stephena Owena.

${ }^{9}$ Opowieść o pięknej Yang Guifei stała się także wdzięcznym tematem dla chińskich sztuk teatralnych, np. Deszcz na drzewie feniksa z 1292 r., czy Pałac wiecznej młodości z 1688 r. 
ców. Rodzice dziewczyny zaprowadzają chłopaka do pustego pokoju ich córki. Młodzieniec przez otwarte okno spostrzega strużkę piasku ciągnącą się aż do rzeki, w piasku odbite są ślady kobiecych stóp. Szukając dziewczyny, znajduje przy rzece parę złotych sandałów. Krótko potem nadchodzi zmierzch i w tym samym momencie chłopak pojmuje, że owa rybacka dziewczyna nie jest nikim innym, tylko samym bodhisattwa Guanyin (oświeconą istotą) (Campbell 1998: 153-154).

Kolejna historia zanotowana w Chinach między rokiem 1573 a 1615., czyli w okresie panowania dynastii Ming, łączy motyw Guanyin z koszem na ryby i z motywem ryby, która przemienia się w potwora. Guanyin przywraca jej jednak pierwotną postać. W innej wersji mitu dobrotliwa Guanyin uwalnia na targu rybnym złowionego syna Króla Smoków, który w rybackich sieciach zmienił się w zwyczajną małą rybę i pozbawiony został pomocy. Guanyin mówi przed tłumem ludzi: „Życie należy się temu, kto próbuje je ratować, nie temu, kto próbuje je odbierać" (Yu 2001: 432). Jej słowa wywierają ogromne wrażenie na tłumie, a Guanyin odnosi rybę do morza. Tam z kolei ryba przemienia się w silnego smoka.

Chun-fang $\mathrm{Yu} \mathrm{w}$ interpretacji opowieści o Guanyin z koszem na ryby podkreśla, że dziewczyna jest pokorna („uniżona”) i że opowieść niesie ze sobą pewną naukę, według której ktokolwiek może zostać zbawicielem w przebraniu, zatem należy być życzliwym dla każdego stworzenia (Beauchamp 2010: 476).

Zreasumujmy teraz $\mathrm{w}$ przejrzystej i uschematyzowanej formie motywowe i tematyczne przenikania narracji, o których była mowa powyżej:

\begin{tabular}{|l|l|l|l|l|l|}
\hline Opowieść o Yexian & $\begin{array}{l}\text { Ramajana/ Da- } \\
\text { szaratha dżaka }\end{array}$ & Manu i ryba & $\begin{array}{c}\text { Opowieść } \\
\text { o Yang Guifei }\end{array}$ & $\begin{array}{c}\text { Opowieść } \\
\text { o Guanyin }\end{array}$ & $\begin{array}{c}\text { Wędrówka } \\
\text { na zachód }\end{array}$ \\
\hline $\begin{array}{l}\text { rywalizacja między } \\
\text { żonami i ich dzieć- } \\
\text { mi }\end{array}$ & $\begin{array}{l}\text { rywalizacja mię- } \\
\text { dzy żonami i ich } \\
\text { dziećmi }\end{array}$ & $\begin{array}{l}\text { rywalizacja } \\
\text { między żonami } \\
\text { i ich dziećmi }\end{array}$ & & & \\
\hline $\begin{array}{l}\text { panowanie drugiej } \\
\text { żony ojca }\end{array}$ & $\begin{array}{l}\text { panowanie dru- } \\
\text { giej żony ojca }\end{array}$ & & & $\begin{array}{l}\text { utrata pierwot- } \\
\text { nego statusu - } \\
\text { życia }\end{array}$ & \\
\hline $\begin{array}{l}\text { utrata pierwotnego } \\
\text { (wysokiego) rodzin- } \\
\text { nego (i społeczne- } \\
\text { go) statusu -perse- } \\
\text { kucja, wygnanie }\end{array}$ & $\begin{array}{l}\text { utrata pierwotne- } \\
\text { go (wysokiego) } \\
\text { rodzinnego (i spo- } \\
\text { lecznego) statusu } \\
\text { - wygnanie }\end{array}$ & $\begin{array}{l}\text { obopólny ratunek } \\
\text { - poświadczenie } \\
\text { miłosierdzia } \\
\text { (Manu i ryba) }\end{array}$ & $\begin{array}{l}\text { poświadczenie } \\
\text { miłosierdzia } \\
\text { (Guanyin jako } \\
\text { bodhisattwa) }\end{array}$ & $\begin{array}{l}\text { obopólny ratunek } \\
\text { - poświadczenie } \\
\text { miłosierdzia }\end{array}$ \\
\hline $\begin{array}{l}\text { obopólny ratunek - } \\
\text { poświadczenie mi- } \\
\text { fosierdzia (Yexian } \\
\text { i ryba) }\end{array}$ & $\begin{array}{l}\text { przez rybę nadna- } \\
\text { turalnej wielkości }\end{array}$ & & $\begin{array}{l}\text { przybieranie } \\
\text { przez rybę nad- } \\
\text { naturalnej wiel- } \\
\text { kości }\end{array}$ & $\begin{array}{l}\text { przybieranie } \\
\text { przez rybę nadna- } \\
\text { turalnej wielkości }\end{array}$ \\
\hline $\begin{array}{l}\text { przybieranie przez } \\
\text { rybę nadnaturalnej } \\
\text { wielkości }\end{array}$ & & & & & \\
\hline
\end{tabular}




\begin{tabular}{|c|c|c|c|c|c|}
\hline Opowieść o Yexian & $\begin{array}{l}\text { Ramajana/ Da- } \\
\text { szaratha dżaka }\end{array}$ & Manu i ryba & $\begin{array}{c}\text { Opowieść } \\
\text { o Yang Guifei }\end{array}$ & $\begin{array}{l}\text { Opowieść } \\
\text { o Guanyin }\end{array}$ & $\begin{array}{l}\text { Wędrówka } \\
\text { na zachód }\end{array}$ \\
\hline $\begin{array}{l}\text { pomoc od „bogów” } \\
\text { (nadprzyrodzony } \\
\text { poseł/ pomocnik) }\end{array}$ & $\begin{array}{l}\text { pomoc od „bo- } \\
\text { gów” (nadprzy- } \\
\text { rodzony posel/ } \\
\text { pomocnik) }\end{array}$ & $\begin{array}{l}\text { pomoc od „bo- } \\
\text { gów” (nadprzy- } \\
\text { rodzony poseł/ } \\
\text { pomocnik) }\end{array}$ & & $\begin{array}{l}\text { pomoc od „bo- } \\
\text { gów” (nadprzy- } \\
\text { rodzony poseł/ } \\
\text { pomocnik) }\end{array}$ & \\
\hline $\begin{array}{l}\text { rola wyszukanych } \\
\text { butów - właściwa } \\
\text { tożsamość }\end{array}$ & $\begin{array}{l}\text { rola wyszuka- } \\
\text { nych butów - } \\
\text { właściwa tożsa- } \\
\text { mość }\end{array}$ & & & & \\
\hline $\begin{array}{l}\text { awansowanie ze } \\
\text { szmat do wznio- } \\
\text { słych szat }\end{array}$ & $\begin{array}{l}\text { awansowanie ze } \\
\text { szmat do wznio- } \\
\text { słych szat } \\
\end{array}$ & & $\begin{array}{l}\text { awansowanie } \\
\text { ze szmat do } \\
\text { wzniosłych szat } \\
\end{array}$ & & \\
\hline ślub z królem & ślub z królem & & ślub z królem & & \\
\hline
\end{tabular}

Powyższa tabela ma pokazać, że opowieść o Yexian czerpie z symboli, motywów i tematycznych algorytmów, wzbogacanych w ciągu stuleci przez wiele azjatyckich kultur. Potwierdzają to także paralele, paradygmatyczne i w syntagmatycznej kolejności zgodne segmenty opowieści o Yexian i wspomniane hinduistyczno-buddyjskie opowieści. Przypomnijmy, że opowieść o Yexian pochodzi z terenu granicznego między Chinami a Wietnamem, wschodnią i południowowschodnią Azją, zatem między obszarami, które dorównywały (poprzez adaptację, adopcję, ale także rezystencję) istnieniu buddyjskich czy hinduistycznych religii.

Beauchamp wygłosiła hipotezę, że w opowieści o Yexian przeplatają się trzy, a nawet cztery różne linie tematyczne. Pierwsze dwie mają swoje korzenie w hinduistycznych narracjach religijnych. W Opowieści o Manu podkreślony został motyw ryby, ratowania tych istnień, które nawzajem okazują sobie miłosierdzie i motyw zagłady - powodzi, podczas której giną stworzenia bezuczuciowe. Druga hinduistyczna narracja, Ramajana, skupia się na motywie macochy, dla której ważniejsze jest jej biologiczne dziecko niż pierworodne dziecko męża: persekucja niewłasnego dziecka zostaje wzmocniona przez obraz utraty pierwotnego ubrania, z wyjątkiem złotych butów, dzięki którym bóg, pod postacią zwierzęcia, rozpoznaje protagonistę. To prowadzi do królewskiego ślubu i wesela. Obie te opowieści adorują monarchię tym, że uwydatniają moralność i boskość króla oraz królowej. Te dwie hinduistyczne historie mogły się wzajemnie przeplatać jeszcze zanim zostały rozpowszechnione na zhunagskim- są zatem co najmniej o tysiąc lat starsze niż opowieść o terytorium Yexian.

Nie są nam znane fakty, które jednoznacznie wykluczałyby przypuszczenie, że opowieść o Kopciuszku ma więcej niezależnych genetycznych ognisk, a wyżej wspomniane typologiczne analogie stanowią po prostu wynik jej transkulturowej uniwersalności. Z drugiej jednak strony, gdybyśmy nie wzięli apriorycznie pod uwagę hipotezy Beauchamp, musielibyśmy przestrzec, że azjatycki kontekst może 
w związku z opowieścią o Yexian dostarczać więcej interpretacyjnych ewentualności: motyw rywalizacji między żonami może pochodzić z kulturowo dominującej Ramajany albo z opowieści o wygnanych i zubożałych Zhuangach (których życie było w okresie dynastii Tang egzystencjalnie niepewne); motyw zgubionego złotego trzewika mógł natomiast być zaczerpnięty albo z opowieści o Site (zagubiona bransoleta przy kostkach nóg) czy złotych sandałach Ramy, albo może po prostu być związana z wyszukanymi pantoflami, wyszywanymi złotem, które dokładnie na miarę ich właścicielki przygotowywały zhuangskie kobiety. Motyw karpia z czerwonymi płetwami i złotymi oczkami może natomiast stanowić wariant Opowieści o Manu i rybie, buddyjskich opowieści i dżatak o inkarnowanym bodhisattawie, albo chodzi po prostu o małą rybkę, którą chwyciła i opiekowała się zwyczajna młoda, zhuangska dziewczyna ${ }^{10}$. Możliwe jednak jest także to, że wymienione interpretacje się nie wykluczają, ale zachodzą na siebie jak puzzle: każda z nich przynosi odmienną perspektywę, która wzbogaca opowieść.

Których elementow opowiadania o Yexian nie znajdziemy we wspomnianych azjatyckich opowieściach, a jednocześnie możemy uznać je za prawdziwie zhuangskie?

Po pierwsze, Zhuangowie zsekularyzowali opowieść. Narracja o Yexian nie zawiera bezpośrednich odniesień do bodhisattawy czy boga.

Druga kwestia wiąże się z tym, że opowieść o Yexian kończy się królewskim ślubem, który jednak nie zapewnia panowania królowi - uzyskane królestwo znajduje się zupełnie gdzieś indziej, król i królowa nie zarządzają swoją ojczyzną, a król jest do tego osobą chciwą, nienasyconą. Beauchamp podkreśla fakt, że Zhuangowie opierali się religii hinduistycznej i buddyjskiej, a tym samym także wyobrażeniu władcy jako kogoś z przyznanym boskim „mandatem z niebios”. Ślub $\mathrm{z}$ „królem” ma służyć w opowieści o Yexian tylko temu, żeby dziewczyna wydostała się z biedy i osamotnienia, ale także po to, żeby uwidoczniona została jej dobroć. Rama, Site i Manu są osobami królewskimi już od urodzenia. Yexian jest tylko córką plemiennego naczelnika.

Trzecia istotna sprawa dotyczy problematyki rodowej. W centrum wspomnianych hinduistycznych opowieści jako wzorce moralne występują Manu i Rama. W opowieści o Yexian "punkt ciężkości” przesuwa się na protagonistkę - jest nią kobieta, która traci rodziców, okazuje swoją dobroć, która cierpi, jest uratowana, rozważna, buntowniczo odmawia pozostania w domu, która jest aktywna i która ostatecznie triumfuje.

Wydaje się, że Zhuangowie dali Kopciuszkowemu cyklowi właśnie te atrybuty, dzięki którym cieszy się popularnością na całym świecie: jego protagonistka jest świecka, kobieca, dziewicza, osamotniona, dobrotliwa, kochająca zwierzęta

${ }^{10}$ Czerwone ryby są znaczącą częścią zhuangskiej kultury wodnej/rybackiej; ryby bowiem były podstawowym źródłem pożywienia wśród Zhuangów. 
i piękne rzeczy. Królową zostaje dzięki temu, że żyje szczęśliwie na świecie, a nie po śmierci. Taki rodzaj opowieści może być popularny w ramach każdej kultury, dlatego że nie zagraża żadnej dominującej religii czy ideologii.

\section{Hipotetyczna migracja opowieści o Yexian do Europy}

Zanim opiszę możliwe sposoby przedostania się opowieści o Yexian do Europy (o ile była rzeczywiście także genetycznie powiązana z historią o Kopciuszku), muszę zaznaczyć, że narracja o Yexian w Chinach w IX w. rozwijała się przy pomocy dwóch trajektorii. Pierwsza z nich wychodziła $\mathrm{z}$ tekstu pisanego (badanie Carrie Reed z 2001 r. wykazuje, że wersja opowieści z 850 r. została nienaruszona, dlatego że Duan Chengshi zapisał ją klasycznym językiem chińskim i w tej postaci była ona następnie kopiowana i drukowana). W drugiej, oralnej trajektorii opowieść rozchodziła się na wiele linii. Jedna z nich wiedzie do historii o Guanyin z koszem na ryby, kolejna natomiast prowadzi do narracji z postacią małpiego króla z chińskiej opowieści Wędrówka na zachód (XVI w.).

Zbiory opowiadań, zawierające różne warianty „Kopciuszka” w Europie prawdopodobnie zaczęły się pojawiać od XVI w. (pierwszy europejski zapis opowieści o Kopciuszku znajdziemy u Francuza Bonawentury des Péries z 1558 roku, choć według naszych badań istnieje mniej znana szkocka opowieść Rashin-Coatie, która zapisana była w księdze Complaynt of Scotland już w 1549 roku). Na stary kontynent, pierwotnie do Włoch, opowiadanie o Kopciuszku mogło się dostać dzięki kupcom, jezuitom i żeglarzom, którzy, przynieśli także inne orientalne opowieści.

\section{Zakończenie}

Wszystkie wspomniane źródła opowieści o Yexian, różnorodne pod względem czasu powstania i kulturowego kontekstu, dotyczą tylko jednego z możliwych rizomatycznych wariantów baśniowego typu 510 A. Ponadto, podczas gdy cytowani badacze uważają tę opowieść właściwie za tekstologicznie namacalny fakt, inni badacze traktują ją jako jedną z możliwych hipotetycznych ewentualności czy nawet za, niepopartą naukowo fantazję.

Tak czy inaczej, narracje o Kopciuszku, ewentualnie ich pierwotne wersje, wykazują transtemporalne (od III w. p.n.e. aż, powiedzmy, do XVII w.), ale również transkulturowe rozproszenie: hipotetyczne genetyczne ogniska tej opowieści są osadzone $\mathrm{w}$ wielu różnorodnych kulturowych kontekstach (Mezopotamia, Egipt, Grecja, Chiny, Indie, Japonia, ewentualnie pogańskie misteria, mity solarne, mistyka chrześcijańsko-żydowska, literatura alchemiczna etc.). 
Niektóre genetyczne ogniska są przy tym weryfikowalne (Yexian Duan Chengshiego, La Gatta Cenerentola Giambattisty Basilego i in.), albo choćby logicznie przypuszczalne (oczywistym jest, na przykład, fakt, że tekst o Yexian nie jest prototekstem, ale zapisem ludowej narracji), inne natomiast są czysto hipotetycznie skonstruowane (np. teoria H. Bayley'a czy R. D. Jameson'a o kopciuszkowych sumeryjskich, egipskich czy indyjskich "pretekstach”).

Ponadto, ta dywersyfikowana sieć może być, w zależności od całkowitego pojęcia genezy $510 \mathrm{~A}$, ukształtowana na podstawie przeciwnych konstytucyjnych zasad: w ramach "dyfuzyjnego" szkicu twórczość narracji 510 A ma dywergencyjny charakter (np. hipoteza Beauchamp - z jednego ogniska rozszerza się poprzez intertekstualne nawiązanie), w ramach archetypalnego szkicu natomiast konwergentny charakter (teoria Junga - z kolektywnej niewiedzy powstaje zgodna narracja w różnych chronotopach).

\section{BIBLIOGRAFIA}

Aarne, A., Thompson S. The Types of the Folktale, Helsinky: FFC, 1961.

Bary, W., Bloom, I. Sources of Chinese Tradition from Earliest Times to 1600. 2nd ed, New York: Columbia University Press, 1999.

Bayley, H. The lost language of symbolism. New York: Barnes \& Noble, 1912.

Beauchamp, F. „Asian Origins of Cinderella. The Zhuang Storyteller of Guangxi. Oral Tradition. Vol. 25/2 (2010).

Campbell, J. Mýty. Legendy dávnych věků v našem denním životě. Praha: Pragma,1998.

Cowel, E. B. The Jataka or Stories of the Buddha's Former Births. London: Luzac, 1957.

Cox, M. R. Marian R. Cinderella. Threehundred and forty-fivevariants. London: The Folk-lore Society, 1893.

Goldman, R. P., Goldman, S. Ramayana. Sundara Kanda. Princeton: University Press, Princeton, 1996.

Jameson, R. D. Cinderella in China, In: Cinderella. A casebook. Ed. By A. Dundes. Wisconsin:, The University of Wisconsin Press, 1982.

Mair, V. The First Recorded Cinderella Story, In: Hawai'i Reader in Traditional Chinese Culture. V. Mair, N. Steinhardt, P. R. Goldin (eds.). Honolulu: University of Hawai'i Press, 2005.

Pace, D. Beyond Morphology: Levi-Strauss and the Analysis of Folktales. In: Cinderella: a Casebook. Ed. By A. Dundes. New York: Wildmen Press, 1983.

Pollock, S. I. Ramayana. Ayodhya Kanda. Princeton: Princeton University Press, 1986.

Reed, C. E. Chinese Chronicles of the Strange: The „Nuogao ji”. New York: Peter Lang, 2001.

Rooth, A. B. The Cinderella cycle. New York: Arno Press, 1951.

Uther, H.-J. The Types of International Folktales. Helsinky: Academia Scientiarum Fennica, 2004.

Waley, A. The Chinese Cinderella Story, In: The Secret History of the Mongols and Other Pieces. London: George Allen, 1963.

Yu, A. C. The Journey to the West. Chicago: University of Chicaco Press, 1977.

Yu, Ch. Kuan-yin. The Chinese Trasformation of Avalokitésvara. New York: Columbia Univerity Press, 2001. 